\title{
Dress as a Reflection of Social Identity and Differentiation in the Soviet Cinema in the 1950s- 1980s
}

Kateryna Novikova, independent researcher.

\begin{abstract}
The paper is based on the visual and sociological interpretation of the specific element of the Soviet everyday life within the period from 1950s till 1980s. From the very beginning, clothing styles and images were used by Communist authorities to impose some important ideological trends on society. There was collectivism, modesty, simplicity, unselfishness, obedience, respect for authority, and hard work in addition to a variety of features of Soviet morality, as well as even more controversial Soviet ideas. Popular culture in the Soviet Union, especially cinema and television, contained both entertainment and propaganda in different proportions. The presented analysis of stories from the selected Soviet movies concerns the specific perspective of the social identity creation, lifestyle construction and imitation strategies of the common Soviet citizens. Social differentiation within clothing styles as symbols of status is shown rather frequently in the movies, especially in the earlier period, as a way to delineate social and moral borders between working class, on the one side, and intelligentsia, on the other.
\end{abstract}

\section{KEYWORDS}

Soviet, Fashion, Identity, Lifestyle, Film Studies

\section{Introduction}

Cinema and fashion have coexisted for many years in harmony and symbiosis; their mutual fascination bonded them from the beginning and it is still flourishing. According to the Polish film researcher and professor of arts Marek Hendrykowski, cinema and fashion have a common origin related to their organic relationship with the history of modern culture. They are both the product of the entrepreneurial and active new middle class from the late nineteenth century. In the first half of the twentieth century they started to bridge stratified social structure with the help of lifestyles that were popular across the society (Hendrykowski 2011, 14).

In the collectivist Soviet society, specific dressing styles were not necessarily a personal choice (as it was to a certain degree in the Western countries) or a means of self-expression. It would be interesting to explore if the relations between cinema and fashion in such specific society as the Soviet one. In what way do movies reflect the Soviet society and lifestyles in their declarative egalitarianism and actual inequality? Or do they represent only element of the totalitarian state propaganda after the World War II? The goal of this paper is to show how certain elements of social identity were created through dress, fashion and diverse lifestyles in the context of social differentiation in the Soviet society. 
Soviet cinema masterpieces and some less popular feature films are selected as relevant and interesting. Some of them were box-office hits and therefore could have a significant impact on the Soviet audience. Among them there is Behind Show Windows (1955), directed by Samson Samsonov; Carnival Night (1956), also known as Carnival in Moscow, Girl Without Address (1957), The Zigzag of Success 1968) and Office Romance (1977), all directed by Eldar Ryazanov; I Love You, Life (1960) directed by Mikhail Yershov; The Girls (1961) directed by Yuriy Chulyukin; There is Such a Lad (1964) and Pechki-łavochki (1972) directed by Vasiliy Shukshyn; Diamond Arm (1969) and Ivan Vasillievich Changes His Profession or Back to Future (1973) directed by Leonid Gayday; Moscow does not believe in tears (1979-80, the 53 ${ }^{\text {rd }}$ Academy Award for the Best Foreign Language film in 1981) directed by Vladimir Menshov and The Most Charming and Attractive (1985) directed by Gerald Bezhanov. In addition to the selected feature films and references to costume design and fashion in general, particular research problems were chosen for this research. They concern fashion as a social statement in terms of belonging to either current or aspired social class and social group, as well as strategies of self-representation and personal identity creation.

\section{Historical Context}

In order to better understand the general social situation, one should remember that the end of the Second World War was overshadowed by the subsequent death of Joseph Stalin. However, society reacted to "the Thaw" not with hope or relief. Overwhelming fear meant that the change would be for worse, not for good. It was not before Khruschev's seminal speech on the personality cult and further public discussions that promising changes and 'symbolic rupture' brought optimism. That optimism signalled improvements in material life, as well as "many people's genuine confidence and pride in their society's ethical and cultural values, political ideas, and prospects for the future" (Gilburd, Kozlov 2013, 32). The Twentieth Congress of the Communist party in 1956 also inspired in some way "the turn to the West" (Gurova 2006, 95). State and party felt not only bigger expectations but pressing demands and impatience for change. Despite various power struggles and some impulse for change, the Soviet political regime remained rather stable. The previous political culture - even the one that was formed under Stalin - persisted. The Khruschev reforms were incomplete along with "the continuing recourse to repressive methods of social discipline, mobilization, and control" (Gilburd, Kozlov 2013, 25). There still was widespread mistrust and secrecy as well as a lasting tendency to blame Soviet society's misfortunes on scapegoats. Despite "the frailty of the Thaw enterprise", as Gilburd and Kozlov emphasized, there was the intense exchange of ideas, growing feeling of greater personal security, and living standards were improving (Gilburd, Kozlov 2013, 25).

The Soviet Union was a deeply divided society "with an almost castelike social system" with top party officials and their families at the top of the social pyramid, followed by the lesser nomenklatura (Seliktar 2015). These were the officials in the party and state bureaucracy that used their position for personal gain and possessed multiple privileges constituting "Soviet aristocracy", it was "a life peerage associated with honours" (Seliktar 2015). Behind the official facade of egalitarian austerity, a whole array of special advantages was created. This special privilege system functioned almost as a "second moneyless economy" for the elite with special stores, hospitals, and 
various preferences based on informal networks and blat connections (Seliktar 2015; Novikova 2015, 191). This extensive system of privileges completely distorted official equality, when society and governmental regime were expected to be "in a transitional stage which will lead increasingly and inevitably to the achievable goal of real equality, i.e. communism, a system without differentiated strata or variations in reward" (Lipset 1973).

\section{Social Differentiation in the Soviet Union}

According to the Soviet experts and economists of the day, a fully egalitarian system was not really possible and desirable to legitimize as well, because people would not accept a truly egalitarian "regimen of work and awards" (Seliktar 2015). The official Soviet image of the social structure of Soviet society was very particular: "one in which there are classes without class antagonisms and without class stratification" (Yanowitch, 1977, 10-11). Those classes included the working class and peasantry, associated with different form of "socialist property", state and cooperative respectively. The "socialist intelligentsia" was an additional structural element described as a social "stratum", not a class. However, the lack of egalitarianism in ideological formulations officially referred to the differing merits of individuals and their differential contribution to production, rather than to class or strata privileges (Yanowitch, 1977, 10-11). In the 1960s, the simplistic threefold division of Soviet society gradually evolved into eight or nine "socio-occupational groups" ranging from unskilled manual workers to "organizers of production collectives" (Yanowitch, 1986, viiviii). They were differentiated by official sociology with respect to economic status, cultural levels, value orientations, and general mode of life. Soviet sociologists did not analysed these groups for the sake of the thorough research of Soviet social groups and social differentiation: the specification was defended on the basis of the practical grounds and the need for social planning and effective management of various social processes in addition to economic planning (Yanowitch 1977).

\section{The Thaw and Lifestyle Changes}

At the turn of the 1960s, intensive economic development and accumulation of the previous reconstruction decade resulted in bigger non-industrial expenses included into Five year plans (Zakharova 2013, 402-403). It was accompanied by some changes in public life, the aforementioned growing optimism and overall enthusiastic atmosphere. At that moment the Soviet Union became more open to the world. International exchanges and contacts were actively developed. Various Soviet delegations travelled abroad more often, and the foreign ones returned the visits. The biggest events of the époque were the World Festival of Youth and Students in Moscow in 1957 and the launch of Sputnik. The growing openness also led to more intensive contacts between the Soviet Union and the West. The Western influences (both in terms of material goods and cultural achievements) were making their way through the Iron Curtain. West became a new reference point unlike it was in the Stalinist 1930s, when the Soviet lifestyle imitated mostly that of the pre-revolutionary educated class and fashion "was supposed to emanate a home-grown Soviet glamour", it was embellished with ethnic motifs with "opulence, decoration, and femininity, which held a wide appeal for the masses" (Gurova 2006, 95; Bartlett 2010, 89). 
In terms of particular ideological limits, fashion was an important process from the very beginning of the Communist rule in Russia and later in other Eastern European countries. During the 1960s, fashion came to the fore of the people's everyday life along with changing art, literature, and public opinion. As Djurdja Bartlett explained in her brilliant book on the development of socialist fashion, "fashion existence - manifested in the regimes' large-scale efforts to maintain it through their central fashion institutions, and to promote it through their women's magazines - showed the socialist system's deep anxieties about the phenomenon of fashion". As she aptly remarked, "fashion was a spectre that haunted socialism. As an ephemeral, incomplete and ever-changing phenomenon, fashion contradicted and seriously challenged socialist values, which were organized around stability, fear of change, predictability, and eternity." (Bartlett 2010, x).

However, at the beginning of the Thaw period "the regimes abandoned harsh repression in favour of more subtle ways of controlling their citizens, and elements of Western modernity were gradually allowed to penetrate everyday life" (Bartlett 2010, 11). These tendencies also concerned fashion in its two main modes - official socialist and everyday fashion, very often home-made or bought as deficit and Western goods through informal connections. Under the conditions of central planning, shortages, and controlled and underdeveloped market fashion, in its classical Western sense, was absent from everyday reality of common Soviet citizens. It required time, money, connections, and respective social status to dress in a fashionable way. An average woman could find only poor-quality clothing in the stores, "the production of good-quality industrial products was unable to meet the demands" (Bartlett 2010, 150). In 1970s, the new idea of dematerialisation confirmed a virtue of modesty in personal appearance and consumption. Commodity fetishism and dependence on things were condemned. Bartlett compared elitism and exclusivity of the "representational socialist fashion" inaccessible for most Soviet people to the everyday fashion. Despite it "existed in an alternative, unofficial modernity and conformed to a different, faster and fragmented concept of time", it was discreetly approved by regime in the form of a controlled and rational practice (Bartlett 2010, 11).

\section{Sources of the Soviet Taste and Fashion}

The possession of consumer goods was not entirely perceived as something negative, it was however closely related to the concept of good taste or Soviet taste. It expressed aesthetically "appropriate consumption practices", established socialist "new middle-class" distinctions, formed a common symbolic space and allowed people for some individualisation in choosing clothing and lifestyles. The Soviet society was gradually absorbing competitive individualism and freedom of self-expression through a variety of images and symbols of consumption. As Gurova suggests, the rise of the idea of Soviet taste and the development of specific discourse around it concerned the opposition of the Soviet lifestyle versus bourgeois or capitalist lifestyle at that time (Gurova 2006, 95). It is similar to Bourdieu's understanding of taste and its justification, where the determination of good taste is achieved via rejection of what is a bad one, by opposing various zones of taste (Bourdieu 2010, 8). 
The phenomenon of imitation of the West, in general, was rather controversial in the Soviet society. From the very beginning, it stood for the "rotten" or "pernicious" Western influence and servility, which meant extreme disloyalty and was criminally punished under the specific legal clause ${ }^{1}$. The Western unofficial cultural capital that was acquired through various communication channels reflected not only lifestyle differentiation, but social differentiation and distinction in general.

In his book on the sociology of taste, Jukka Gronow shows a particular discussion on whether it was decent for a Soviet person to underline and show off one's social position. He concludes that problem of low quality of design and less popularity of the socialist style in the world is linked not only to the inflexibility of production system or planned economy. There was a very rigid system of social distinctions with "its inherently imposed self-limitations". Acceptable distinctions were not supposed to violate "respectable and cultured manners" (Gronow 2002, 65-66). In her concept of the Soviet Big Deal, Vera Dunham explained the division between the intelligentsia and lower middle class meshchanstvo with the help of such untranslatable words as kultura and kulturnost' (culture and 'culturedness'). "Kultura is the achievement of the intelligentsia in the sense of a higher culture, a synthesis of ideas, knowledge, and memories". The other word represents a sort of second-hand notion, "a mere program for proper conduct in public" according to some prescribed preferences, "a new kind of self-righteousness - stable, prudent, heavy", "the self-image of dignified citizens (Dunham 1990, 22). According to Dunham, kulturnost' conferred the attributes of virtue and dignity to material possessions. Following Dunham, Gronow summarized the morals of "the new Soviet middle class" in a particular way. "Inequality, the aspirations of higher income and better material living standards, and a better life, are legitimate insofar as they are righteously earned by one's own labour and/or talents" (Gronow 2002, 61).

In this paper, social differentiation, as well as status differences or inequality are not considered a basis for fashion and top-down imitation of prestigious lifestyles (Blumer 1967, 278; Svendsen 2006, 42-43; Novikova 2017, 59). However, it is assumed that a dress symbolizes lifestyle and social affiliation, and influences personal image and self. More than one hundred years ago, a German sociologist Georg Simmel emphasized the connection between fashion and identity, which in modern age was no longer provided by tradition. So, in the Western world clothes have become a vital part of the social construction of the self, and fashion is not just about class, status or social differentiation, but just as much as about expressing one's individuality (Svendsen 2006, 19). In the Soviet Union, the nature of consumer culture and fashion was defined not only and not so much by income, but by the attitude toward fashion. It meant that income disparities were necessarily an obstacle to dressing in a stylish way. That was, for instance, the reason for extraordinary development of custom tailoring. "Fashionable clothing was made in various ways: by consumers on their own, by professional seamstresses in tailor shops, and by semi-professional private tailors" (Zakharova 2013, 417-421).

In his analysis of fashion and cinema in the socialist Poland, Hendrykowski mentions a zero style concept by Roland Barthes. As a great illustration of a "hopeless greyness" of available massproduced clothing, it reflected the life philosophy of "go with the flow" and social mimicry. However, in socialist Poland it was caused rather by overall poverty than by deliberate solution of

\footnotetext{
1 “За преклонение перед Западом”, that is so called "kowtowing before the West”, (Zubkova 2015, 119).
} 
the question "To be different, or to be the same?" (Hendrykowski 2011, 112-113). In the Soviet context, in addition to grey black, beige and white were the real colours of fashion design, neutrality, and "visible invisibility" (Gurova 2009, 84). In the ideology of Soviet taste, such differentiation was related to the opposition between Western style and good Soviet culture, "between authentic beauty and artificial prettiness". Furthermore, "public opinion considered the desire to be different in clothes or appearance to be vulgar" (Gurova 2006, 96). During the later post-war period, the Soviet people made their own choices based on self-expression, self-fulfilment, idiosyncrasy, distinction, and even freedom to escape from the ubiquitous dullness and uniformity.

\section{Cinema in the Soviet Union}

These processes have been analysed in this paper on the basis of the Soviet feature films. As Gilburd and Kozlov underlined in their analysis of the social changes during the Thaw transformation period, the movies of 1950s and 1960s not only registered the changes the best, they showed new dress, gestures, bearings, and altered perception and behaviours (Gilburd, Kozlov 2013, 27). New example and looks were accessible to emulate for growing audiences of the greatest pieces of the Soviet cinematic art that performed perfectly as a mechanism for mythmaking (Lipovetsky 2002, 161). Being a source of social skills or 'savoir-vivre' for the Soviet audience, cinema - both of Soviet and Western productions - also represented the source of role models, various images to copy and identities to choose.

The researchers of the Soviet cinema described the Thaw, and the 1960s in particular, as the period of visible change. It was related to relaxing censorship, starting real dialogue with contemporary Western culture, as well as with new discursive concepts of memory, truth and sincerity (Bulgakowa 2013, 476). "Numerous films of the period showed the immediate effect of the Thaw on the present and focused on family life. Filmmakers were encouraged to be truthful and authentic, and to avoid the glossy portrayal and falsification of the Stalin era film" (Beumers 2009, 128). The personalities of main male and female characters are shown full of ordinary human feelings, needs and shortcomings, both during daily routine activities and festive events. However, some social and status markers were applied to show the complex picture of modern society. Among them, dress and consumption of goods occupied a rather important place. One should take a closer look at the selected movies, their plots and characters.

\section{Soviet Films, Fashion and Identity}

In one of the earlier post-Stalin movies Behind Show Windows (Samson Samsonov, 1955), the topic of retail, consumption and even fashion appears in terms of originality, individuality and identity construction. The scene is laid in the men's suits department of a large department store. Due to some complications - obviously of the socialist planned economy character with no such explanation, of course - suits are of extremely bad quality. The main male character, a department manager is refusing to accept these suits arguing with the garment factory manager, a main female character and his future affection. The argument concerns the mass-oriented production. As a department manager concludes, "every mass-oriented suit becomes deeply personal for our customer!" Each customer has a right for a very good-quality individualized clothing. The movie 
shows an extremely romantic, utopian or even propagandist vision of a Soviet department store and its consumers. It echoes, however, the Western lifestyles, but in Khrushchev's way of competition with the West. Even in sartorial terms the Soviet country was supposed to "catch up and overtake" the West (Bartlett 2010, ix). It is interesting that in the movie, there is still no reference to fashion and its changing nature. It is rather about a good Soviet taste and quality in the first place.

During the mid-1950s, another box-office hit came out by the title Carnival night or Carnival in Moscow (Eldar Ryazanov, 1956). The depiction of Soviet life is also very polished in this musical, especially in the context of the chances and lifestyles of ordinary people and elite. It is clearly referring to the anticipated glorious future of Communism. In the movie, the future is already here. The representatives of Soviet working class and some of intelligentsia stratum enjoy - at least during the carnival night - a really high level of life having their holidays and leisure organized in an almost luxurious style. The entertainment program includes a lot of dancing and singing, jazz band performance, and even magic tricks. All the characters, and especially the main female character, are wearing stylish dresses. There is an opposition in the movie - a bureaucrat, placeman and verbalist - the new director of the cultural played by a popular comedian. This local official is dull and conformist, afraid and subservient to other more prominent officials. In the end, these representatives of the Soviet elite are more approachable and clearheaded than the entrenched bureaucrat who forbids short skirts of the female dancing groups and closes down the performance of jazz orchestra.

The late 1950s and early 1960s embraced the period when Soviet fashion started to get institutionalized on the screen as well. The films shaped the approach towards fashion, fashion houses and in general the role of consumption. In the movie Girl without address (Eldar Ryazanov, 1957), a young woman is taking part in a show as a model. While looking for a job in a big city she is convinced to take part by a recruiter and an enthusiastic Soviet designer looking for models on the street. The show was complex and presented many types of dresses from workwear to wedding dresses. The job however was not serious enough for the main character. She is choosing to go somewhere far away - most obviously to the East - to work as a bricklayer on the construction sites and build something more fundamental.

The movie There is Such a Lad (Vasiliy Shukshin, 1964) represents another great illustration of the role of fashion and dress in the Soviet society (in this case, of its provincial type). The main male character is a kind, funny, and outgoing person, who loves life. He is informing his friends about a sort of a mobile fashion show, which is going to take place later that night. His enthusiastic attitude to beautiful models refers first of all to their physical appearance. Remark "the legs are that thin" is almost related to the Twiggy type from 1960s in the Western fashion. At the show, there is a presenter explaining dress, its structure, role, and especially its socialist concept: "our clothes are beautiful, simple and comfortable, and functional". According to her, one's dress should correspond with one's profession and job, one should not wear garish clothes because of their tastelessness and so on. The whole show is full of elements of the good Soviet taste and socialist style. The movie is obviously supposed to teach its audience about it. 
In the movie, there is another interesting point concerning a certain type of taste, lifestyle, and dress. It is a discussion between the main character, who was a truck-driver, and his fellow road tripper. She is evidently an urban dweller, and they are discussing tastelessness of 'merchant' consumerism and possession of numerous unnecessary old-fashioned things. "Life can be beautiful, even if we start with details". Among her advices, there is minimalism and modern approach. For example, an old frantic bed with lots of pillows should be thrown away, instead, a modern ottoman would be an ideal decoration. Later, the main character develops this point. He is making a great conclusion about one of the most obvious dichotomies or differentiation criteria in the Soviet society: urban vs. rural ("you are so outdated (here, in the village). Guys prefer courting urban girls because one can even talk about interesting things with them)." In the end, he is getting to know a stylish urban girl. A journalist visits him in a hospital and delights him with her stylish look, voice and a generally "cultural" image.

Another criterion of social differentiation is a specific Soviet class and social background. The most interesting situation is shown in a not very popular but really interesting movie I Love You, Life (Mikhail Yershov, 1960). The main male character works as an engineer at a candy factory. He has very prominent parents but rather in terms of achievements and merits, including those from the wartime. Also, he has a beautiful, stylish and educated girlfriend, who is also an engineer and has prominent and influential parents. In one of the movie scenes, she is emphasizing current changes, easier life compared to the previous revolutionary and wartime periods. However, she is obviously losing to a modest, less refined Soviet girl, an ordinary worker at the candy factory. Despite the New Look dresses, jazz music, and modish and somewhat strange - as a viewer must think - dances of his girlfriend, the main protagonist ultimately makes his proper choice. He continues his struggle of an ordinary Soviet citizen for the better and glorious future with no penchant for comfort or luxury.

However, not all the urban dwellers or intelligentsia representatives are rich and well-doing. Money is the main topic of the comedy The Zigzag of Success (Eldar Ryazanov, 1968), where one of the protagonists cannot afford to buy a beautiful costume from behind the store window. This is the only way she can find happiness in love. A part of a big lottery win let her become stylish and beautiful (that is almost another person) and to find a husband.

The issue of the price of good nice clothes appears in Vasiliy Shukshyn's movie Pechki-Lavochki (aka Happy Go Lucky, 1972). In this film, the main female character receives a nice and expensive chemisette as an unexpected gift from a fellow train traveller. This thing turned to be from a stolen luggage. At the very beginning, she realizes that this chemisette is not a proper thing for her. It looks too expensive, and she is an ordinary rural woman. She would never spend that much money for a thing to wear and therefore this is not her style.

There is obvious sympathy for the ordinary people, and this is rather logical for such an egalitarian society. In the movie The Girls (Yuriy Chulyukin, 1961), there is a noteworthy differentiation. The social background represents the main differentiating factor. Age and experience are of secondary importance. Moreover, the audience is supposed to be sympathetic with the female character who is younger, poorer, more naïve, unremarkable and orphan main character in the movie. She has stronger principles than her more stylish, educated but arrogant, and shameless rival. Certainly, 
according to cinematic conventions, the happy end comes to the powerless and humiliated. The distinguishing issue is a moral one though young women desiring to be beautiful, stylish, and happy in their love lives.

The same judgement appears in the famous box-office hit Ivan Vasillievich Changes His Profession or Back to Future (Leonid Gayday, 1973). In this movie, the negative fictional counterpart of the main female character cheats on her husband, a noted scholar and inventor of the time machine. As a popular actress, she wears very fashionable clothes and is involved in some informal relations and blat to get access to such clothing (an iconic sheepskin coat). In the end, it turns out that the whole fiction is the inventor's dream and his wife is faithful, reserved and down-dressed girl wearing glasses.

Another popular top-box comedy, Diamond Arm (Leonid Gayday, 1969), shows the similar difference between classes and their supposed lifestyles and refers to strong elements of shadow economy. There is a good though somewhat naïve male character. He is an accountant, wears ordinary modest clothes, of obviously Soviet production. So do his wife and most of the neighbours. Among the swindlers, there are more stylish characters with Western-styled clothes. One of them is taking part in the fashion show featured in the movie revealing his profession. In the Soviet society, fashion house and modelling raised suspicion and evoked the associations with something uncontrollable or at least something that should be controlled. In the end, richer and more stylish swindlers lose and the good militiamen in a uniform, as well as an ordinary Soviet citizen wearing beige, win the battle.

The Moscow does not believe in tears (Vladimir Menshov, 1980) presents the most complex picture. In this movie, social differentiation and inequality draws on the social background. It is also reflected in behaviour, clothing and generally in lifestyle. There is however an allusion to great opportunities of social mobility in the Soviet society. Many people migrated as a result of the intensive industrialisation and urbanisation processes before the war and great reconstruction after it. During the 1960s, one fifth of the population moved from the countryside to cities. Among them, there are so called limitchiks in Moscow. This is a specific term for people registered in the Soviet capital or other big cities as a result of the quotas on migration (Boym 2005, 128-129). Most Soviet urban dwellers were first-generation ones. They were pulled out of the traditional rural environment, left atomized in the alien milieu without civil maturity and necessary social skills. On the one hand, social mobility was facilitated by free education, but on the other - regulated with the non-economic restraints, which made education closely connected to specifically Soviet social differentiation, status systems, and prestige. Later on, all this resulted in the closure of the higher social groups and further intensification of social stratification of the Soviet society.

In the movie, one of the female characters is the most stylish, wears beautiful dresses and behaves in a specific "cultural" way to emphasize that she is different. In fact, she chooses this lifestyle to look different, to be distinctive among the people of her social strata and their specific standardized lifestyle, Soviet taste and kulturnost'. This distinction is a part of her consistent strategy to get "a better life in this lottery called Moscow". Sadly, in the Moscow Does Not Believe in Tears the most distinctive and stylish character is unhappy in her personal life. 
Personal problems, love and companionship are closely connected with new clothes and new identity in the famous box-office hit Office Romance (Eldar Ryazanov, 1977). In general, the film emphasizes the close connection between success, ability to follow fashion trends, and femininity. The main female character is a successful Soviet woman, a head of the fictional statistical bureau in Moscow, relentlessly committed to work, reserved and heartless. Thanks to romantic relationship and assistance of her stylish secretary she becomes a very attractive and charismatic person. A chic dress, make-up and haircut are obviously enough to acquire a new identity or even start a new life. However, there is also a specific type of differentiation of the typically Soviet character. On the one hand, the secretary - a fashion icon - is praised by her colleagues for her ability to "wear only foreign-made clothes despite her modest salary". On the other, there is another character, a man of success. He is promoted to vice-head, but at the same time is implicitly mocked at for his big and expensive Volga car, extravagant home interior design or unimaginable for an ordinary Soviet clerk - the Swiss period in career he mentions on every occasion.

\section{Conclusion}

There are more Soviet movies that have numerous relevant references to the topic of fashionable or ordinary clothing, and its connection to the social differentiation or identity in the Soviet Union. For example, Domestic Circumstances (Aleksey Korenev, 1977), The Most Charming and Attractive (Gerald Bezhanov, 1985), The Messenger (Karen Shakhnazarov, 1986), We are Cheerful, Happy, Talented! (Aleksandr Surin, 1986), Lonely Woman Seeks Lifetime Companion (Vyacheslav Kristofovich, 1986), among others. However, the analysis of the above-mentioned movies gives us several interesting examples of how the perception of clothing and social differentiation can be shaped by popular culture and movies in particular. Among the main themes, there are the differences between rural and urban lifestyles, as well as the Western and local production of clothing. In the Soviet movies of 1950s and 1960s, there is a strong differentiation between artificiality, imitation and hypocrisy of the fashionable looks of the intelligentsia and usually evildoers, on the one side, and the authenticity of the simple but pure looks of the ordinary workers or representatives of the Soviet people, on the other. Later, however, the issue concerning personal happiness - especially for women - and self-fulfilment, becomes more important as a part of individual, as well as a social identity of the movie protagonists and their viewers. In 1970s-1980s, beautiful, Western, more fashionable clothes result in a prettier look and better future in terms of both private and public life.

\section{References}

Bartlett, D. (2010) FashionEast: The Spectre that Haunted Socialism. Cambridge, MA: MIT Press.

Beumers, B. (2009) The History of Russian Cinema. Oxford: Berg.

Blumer, H. (1969) 'Fashion: From Class Differentiation to Collective Selection'. The Sociological Quarterly. Volume 10, Issue 3, s. 275-291. 
Bourdieu, P. (2010) Distinction. A Social Critique of the Judgement of Taste. London, New York: Routledge.

Bulgakowa. O (2013) 'Cine-Weathers: Soviet Thaw Cinema in the International Context'. D. Kozlov, E. Gilburd, The Thaw: Soviet Society and Culture during the 1950s and 1960s. Toronto: University of Toronto Press.

Dunham, V. (1990) In Stalin's Time: Middleclass Values in Soviet Fiction. Durham: Duke University Press.

Gilburd, E. and D. Kozlov (2013) 'The Thaw as an Event in Russian History', D. Kozlov, E. Gilburd, The Thaw: Soviet Society and Culture during the 1950s and 1960s. Toronto: University of Toronto Press, 18-77.

Gurova, O. (2006) Ideology of Consumption in Soviet Union. From Asceticism to the Legitimating of Consumer Goods. Anthropology of East Europe Review. Vol 24, No 2, 91 98.

Gurova, O. (2009) 'The Art of Dressing: Body, Gender and Discourse on Fashion in Soviet Russia in the 1950s and the 1960s', E. Paulicelly \& H. Clark, eds., The Fabric of Cultures. Fashion, Identity, Globalization. London, New York: Routledge, 2009, 73-91.

Gronow, J. (2002) The Sociology of Taste. London, New York: Routledge. Hendrykowski, M. (2011) Film i moda. Poznań: Wydawnictwo Naukowe UAM. Boym, S. (2005) 'Perestroika of kitsch: Sergei Soloviev's Black Rose, Red Rose'. A. Horton, Inside Soviet Film Satire. Cambridge: Cambridge University Press, 125-137.

Finkelstein, J. (2007) The Art of Self-Invention. Image and Identity in Popular Visual Culture. New York: I.B.Tauris.

Lipovetsky, G. (1994) The Empire of Fashion. Dressing Modern Democracy. Princeton: Princeton University Press.

Lipset, S. M. (1973) 'Commentary: Social Stratification Research and Soviet Scholarship'. International Journal of Sociology. Vol. 3, Issue 1/2.

Novikova, K. (2017) Imitacja w wybranych koncepcjach i kontekstach społecznokulturowych. Józefów: Wydawnictwo WSGE.

Novikova, K. (2015) 'Informal Networking as Effective Resource and Sociocultural Traditions of Homo Sovieticus'. Zeszyty Naukowe UPH. Seria: Administracja $i$ Zarządzanie, nr 104/2015, 187-194.

Roberts, G. H. (2017) Material Culture in Russian and the USSR: Things, Values, Identities. London: Bloomsbury Publishing.

Seliktar, O. (2015) Politics, Paradigms, and Intelligence Failures: Why So Few Predicted the Collapse of the Soviet Union: Why So Few Predicted the Collapse of the Soviet Union. London New York: Routledge.

Svendsen, L. (2006) Fashion: A Philosophy. London: Reaktion Books.

Yanowitch, M. (1977) Social and Economic Inequality in the Soviet Union. London, New York: Routledge.

Yanowitch, M. (ed.) (1986) The Social Structure of the USSR. Recent Soviet Studies. London, New York: Routledge. 
Zakharova, L. (2013) 'Soviet Fashion in the 1950s-1960s: Regimentation, Western Influences, and Consumption Strategies', D. Kozlov, E. Gilburd, The Thaw: Soviet Society and Culture during the 1950s and 1960s. Toronto: University of Toronto Press.

Zubkova, E. (2015) Russia After the War: Hopes, Illusions and Disappointments, 19451957. London, New York: Routledge.

\section{Biography}

Kateryna Novikova, $\mathrm{PhD}$ in Sociology of Contemporary Societies (John Paul II Catholic University of Lublin, Poland), MA in Central European History (Central European University, Budapest, Hungary). Research interests include sociology of work and creativity, lifestyles and leisure, networking and new media discourses as well as the issues of the postsocialist and postSoviet social and cultural capital.

email: kate_novi@hotmail.com 